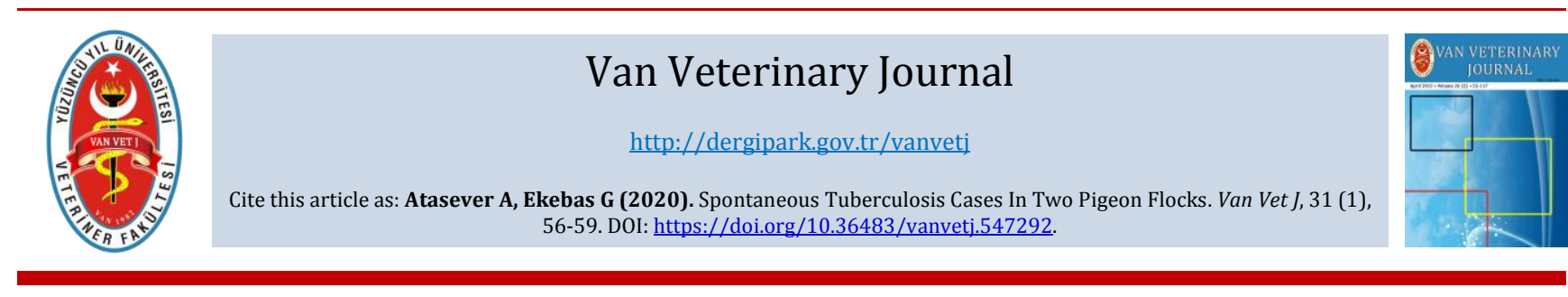

\title{
Spontaneous Tuberculosis Cases In Two Pigeon Flocks
}

\author{
Ayhan ATASEVER Görkem EKEBAȘ® \\ Erciyes University, Faculty of Veterinary Medicine, Department of Patology, Kayseri, Turkey
}

Received: 01.04.2019

Accepted: 04.12.2019

\begin{abstract}
In this study, a 2-year-old female rock pigeon and two 4-month-old tumbler domestic pigeon brought to Erciyes University, Faculty of Veterinary Medicine, Department of Pathology, for necropsy were diagnosed as tuberculosis. On the macroscopic examination, several nodules with yellowish colour were seen in the pulmonary sections as well as in the rock pigeon. The grey-yellowish nodules were found on the right wings ( $1 \times 1.5 \times 0.8 \mathrm{~cm}$ in size), the liver surface and the jejunum in the small intestine (with a size ranging from 0.5 $1 \mathrm{~mm}$ to $1 \mathrm{~cm})$ and near the craw $(0.3 \times 0.8 \mathrm{~cm}$ in size $)$ of the one tumbler pigeon. In other, grey-yellowish nodular structures were seen in the lungs $1 \times 1.2 \times 0.5 \mathrm{~cm}$ and $0.5 \times 0.7 \times 0.6 \mathrm{~cm}$ in the liver. Histopathological examination showed that these lesions were tuberculous lesions consisting of homogeneous eosinophilic colourized casein necrosis, surrounding multi-nucleated giant cells, epithelioid histiocytes, histiocytes, lymphocytes and, most extensively, typical tubercles with a fibrous capsule. According to In the Ziehl-Neelsen staining, tuberculous bacillus was not observed in the tissue of rock pigeon, while tuberculous bacillus was found in a large number of dense red in tubercle structures in both of the tumbler pigeons. Because of the zoonotic nature of the agent and the risk of contamination, it was evaluated as a case report.
\end{abstract}

Keywords: Histopathology, Pigeon, Tuberculosis

öz

\section{İki Güvercin Sürüsünde Spontanöz Tüberküloz Vakaları}

Bu çalışmada, Erciyes Üniversitesi Veteriner Fakültesi Patoloji Anabilim Dalı'na nekropsi amacıyla getirilen 2 yaşlı dişi kaya-cami güvercini ve 4 aylık 2 adet evcil taklacı güvercinde tüberküloz olgusu tanımlandı. Makroskobik incelemede, kaya güvercininde kaşektik tablo ile birlikte akciğer kesitlerinde toplu iğne başı büyüklügünde sarımtırak renkte birkaç nodül görüldü. Taklacı güvercinlerin bir tanesinin sağ kanat altında gri-sarımtırak renkte 1 x 1.5 x $0.8 \mathrm{~cm}$ ebatlarında, karaciğer yüzeyinde ve barsakta jejunum üzerinde $0.5-1$ mm'den $1 \mathrm{~cm}$ 'ye kadar değișen büyüklükte, kursağa yakın $0.3 \times 0.8 \mathrm{~cm}$ 'lik gri-sarımtırak renkte nodüllerin varlığı dikkati çekti. Diğer taklacı güvercinde ise akciğerde $1 \times 1.2 \times 0.5 \mathrm{~cm}$ ve karaciğerde $0.5 \times 0.7 \times 0.6 \mathrm{~cm}$ ebatlarında gri-sarımtırak renkte nodüler yapılar görüldü. Histopatolojik incelemede bu nodüller lezyonların homojen eozinofilik renkte kazeifikasyon nekrozu olduğu, bunların çevresinde çok çekirdekli dev hücreleri, epiteloid histiyositler, histiyosit, lenfosit ve en dișta da fibröz bir kapsülden oluşan tipik tüberküllerden oluşan tüberküloz lezyonları olduğu gözlendi. Yapılan Ziehl-Neelsen boyamasında kaya güvercininde tüberküloz basilleri gözlenmezken, taklacı güvercinlerin her ikisinde de tüberkül yapılarında çok sayıda yoğun kırmızı renkte küçük kümeler halinde tüberküloz basilleri tespit edildi. Etkenin zoonoz karakterde olması ve kontaminasyon riski nedeniyle olgu sunumu şeklinde değerlendirilmiştir.

Anahtar Kelimeler: Güvercin, Histopatoloji, Tüberküloz

\section{INTRODUCTION}

Tuberculosis is a chronic and contagious disease caused by Mycobacterium avium in poultry (Thoen and Karlson 1991). Although most of the poultry tuberculosis is reported in chickens (Gonzalez et al. 2002), it has also been reported in turkey (Gerhold and Fischer 2005), goose (Oruç and Bali 2004), pigeon (Bougiouklis 2005; Terim Kapakin et al. 2010; Terim Kapakin and Alçı̆̆ır 2009), ostrich (Garcia et al. 2001), quail (Tell et al. 2003), pheasant (Hsieh et al. 2009), psittacine birds (Lennox 2007), parrots, budgerigars, canaries, eagles and other domestic and wild birds (Thoen and Karlson 1991). In particular, while pigeons are highly resistant to M. avium infection, pheasants are susceptible to disease (Singbeil et al. 1993; Hejlicek and Treml 1994).

In poultry tuberculosis without clinical-pathological findings, the transmission is transmitted through respiration and digestion (infected feed and water), so that infected birds can infect each other and humans (Thoen 
and Karlson 1991; Möbius et al. 2006; Fulton and Thoen 2000; Özcan et al. 2001; Kriz et al. 2010).

In recent years, the zoonosis tuberculosis has been observed in the pigeons, was fed for a hobby. Due to effects on public health, this research plays an important role in providing different perspective on literature.

\section{CASE HISTORY}

In the study, cachexia 2 years old, a female rock- mosque pigeon (Columba livia) and cachectic and other nondiarrhea without any signs of death were seen in two 4month old tumbler pigeons (Columba domestica) were brought in the Erciyes University, Faculty of Veterinary Pathology Department in order to necropsy.

In this study 200 food handlers from different plants were interviewed. Questionnaires were responded individually, in the presence of the researcher, 30 minutes time required for completion.

Tissue samples from pigeons with systemic necropsy were detected in $10 \%$ buffered formaldehyde. The detected tissues were blocked after trimming and the sections of 56 micron thickness were stained with hematoxylin-eosin (HE). In addition, selected sections were stained with Ziehl-Neelsen (ZN) method and evaluated under a light microscope.

In rock pigeon necropsy, no macroscopic lesion was found except a few yellowish nodules on the lung sections. In the necropsy of one tumbler pigeon, one nodule, $1 \times 1.5 \times 0.8$ $\mathrm{cm}$, (Figure 1A) was located under right wing of one of them, other was on the surface of liver that has grown considerably and has a size ranging from $0.5-1 \mathrm{~mm}$ to $1 \mathrm{~cm}$ (Figure 1B) and on the jejunum of the intestine (Figure 1C). The grey-yellowish nodules, $0.3 \times 0.8 \mathrm{~cm}$, were found near the craw (Figure 1D). $1 \times 1.2 \times 0.5 \mathrm{~cm}$ (Figure 2A) and $0.5 \times 0.7 \times 0.6 \mathrm{~cm}$ grey-yellowish nodular (Figure 2B) were seen in the lung and in the liver, respectively in the other tumbler pigeon.

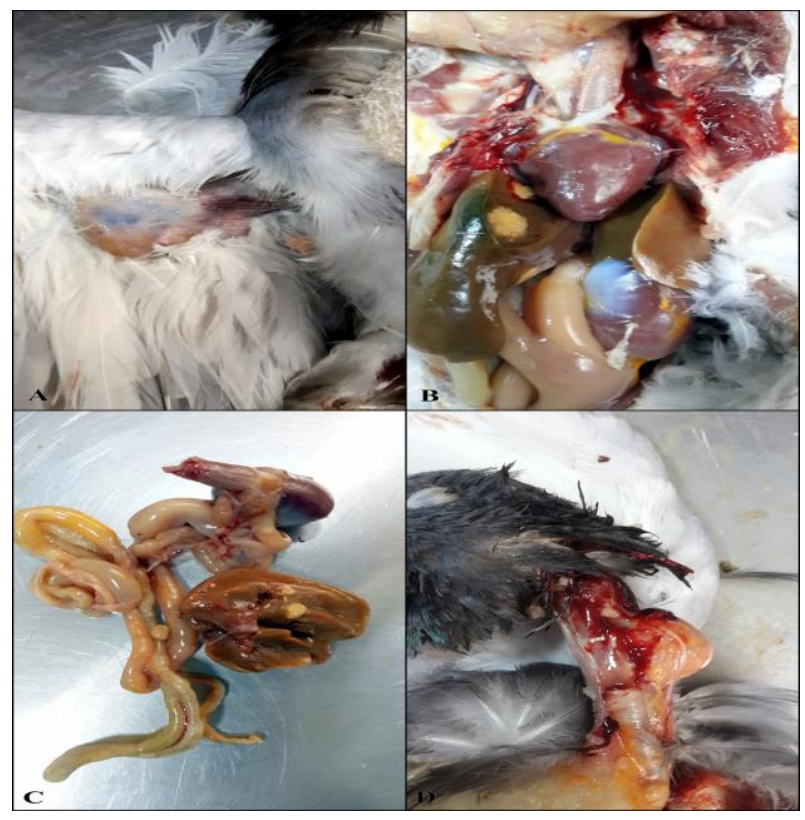

Figure 1. A. View of the mass of $1 \times 1,5 \times 0,8 \mathrm{~cm}$ in grayyellowish color under wing. B. The appearance of nodular structures ranging from $0.5-1 \mathrm{~mm}$ to $1 \mathrm{~cm}$ on the enlarged liver surface. C-D. Appearance of gray-yellowish nodules $0,3 \times 0,8 \mathrm{~cm}$ on the jejunum.

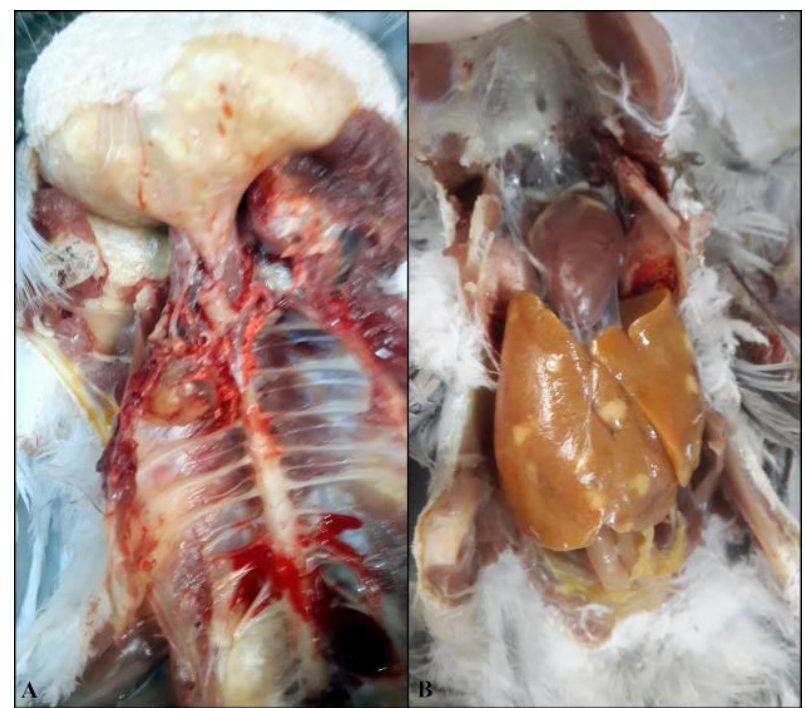

Figure 2. Lung $1 \times 1,2 \times 0,5 \mathrm{~cm}(\mathrm{~A})$, liver in the size of $0.5 \times 0.7 \times 0.6 \mathrm{~cm}$ (B) size of the gray-yellowish-colored nodular structures.

Histopathological examination showed that these lesions were tuberculous lesions consisting of homogeneous eosinophilic colourized casein necrosis, surrounding multi-nucleated giant cells, epithelioid histiocytes, histiocytes, lymphocytes and, most extensively, typical tubercles with a fibrous capsule in the rock pigeon of lung and spleen (Figure 3 A, B, C, D). Tuberculosis bacilli were not observed in Ziehl-Neelsen staining. In both of the tumbler pigeons, several caseous necroses of homogenous eosinophilic including multiple masses in the lungs, liver, spleen and intestines, below the wings, multinucleated giant cells, epithelioid histiocytes, histiocytes, lymphocytes and extrinsic a fibrous capsule are observed. (Figure 4 A, B, C, D, E). In Ziehl-Neelsen staining, tubercles were observed in small mass of tuberculosis bacilli (Figure $4 \mathrm{~A}^{\prime}, \mathrm{B}^{\prime}, \mathrm{C}^{\prime}, \mathrm{D}^{\prime}$, E').

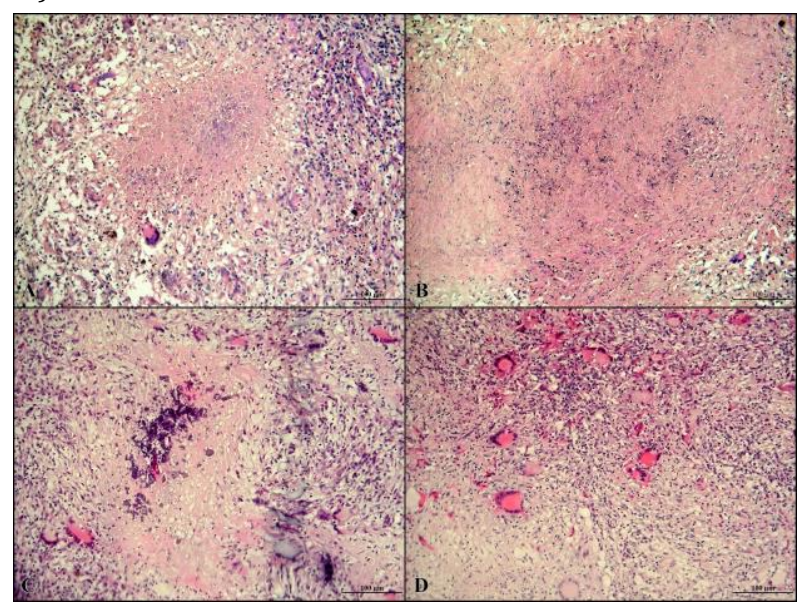

Figure 3. The appearance of typical tubercle structures in the lungs $(A, B, C)$, in the homogenous eosinophilic case, in case of necrosis of caseinification, multinucleated giant cells around it, epitheloid histiocytes, histiocytes, lymphocytes and a fibrous capsule at the outermost. Necrosis of caseinification in the spleen (D) homogenous eosinophilic color, the appearance of multinucleated giant cells around them, $\mathrm{H} \times \mathrm{E}$. 


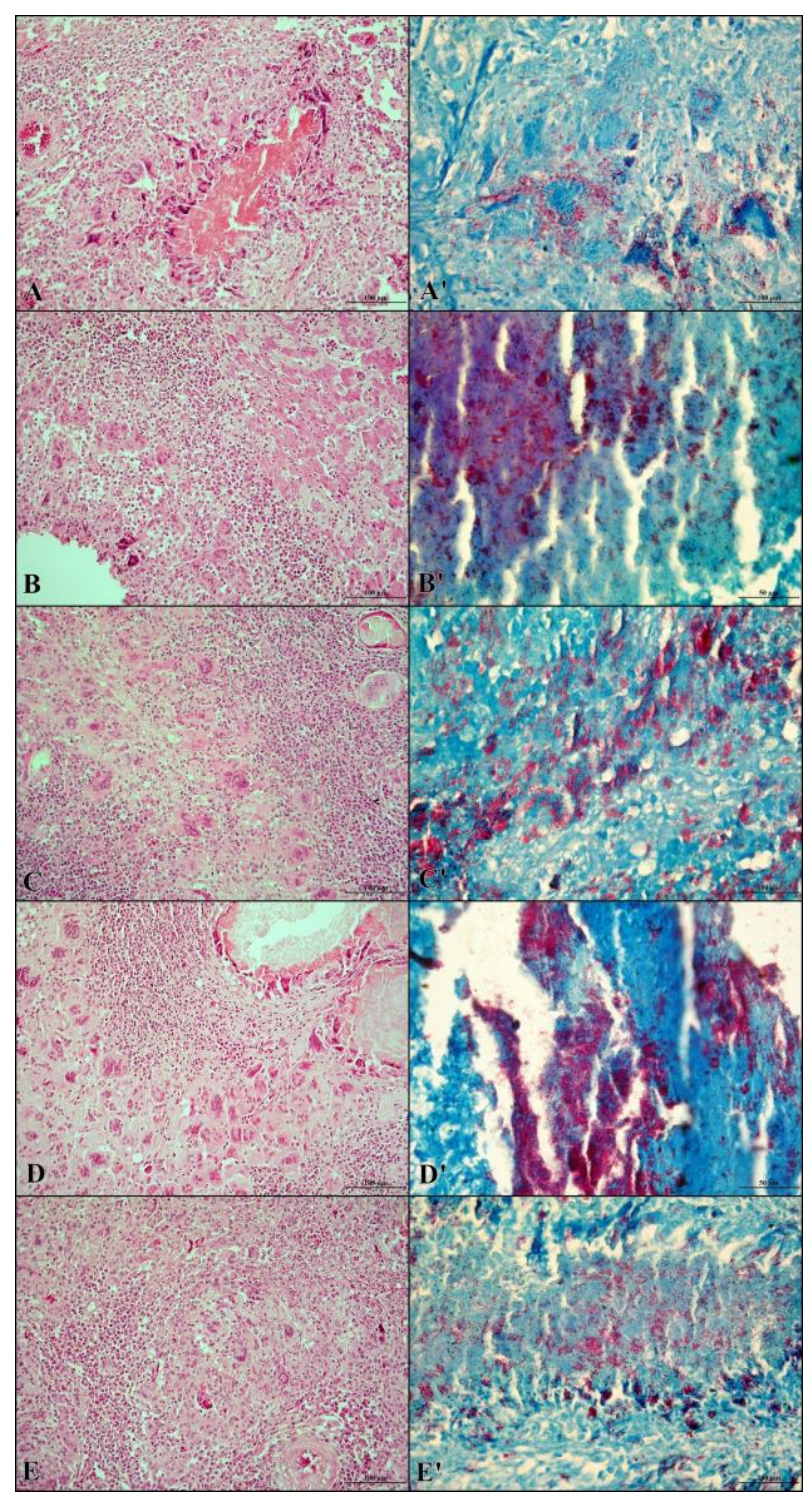

Figure 4. Lung (A), liver (B), mass under wing (C), spleen (D) and intestine necrosis focuses on homogenous eosinophilic color in intestines (E), multinucleated giant cells around them, epithelioid histiocytes, histiocytes, lymphocytes and the outermost appearance of typical tubercle structures consisting of a fibrous capsule, HxE. Tuberculosis bacilli in small clusters in the tubercle structures found in the lung $\left(A^{\prime}\right)$, liver $\left(B^{\prime}\right)$, mass under the wing $\left(C^{\prime}\right)$, spleen (D') and intestines ( $\left.E^{\prime}\right), \mathrm{ZN}$.

\section{DISCUSSION}

Rarely, tuberculosis in domestic animals has been observed and not only tuberculosis but also poultry tuberculosis has played an important role in zoonotic infections. Therefore, poultry tuberculosis is a disease with high mortality and morbidity and is of great importance because it is highly contagious (Fulton and Thoen 2000;

\section{REFERENCES}

Bougiouklis P, Brellou G, Fragkiadaki E, Iordanidis P, Vlemmas I, Georgopoulou I (2005). Outbreak of Avian Mycobacteriosis in a flock of two-year-old domestic pigeons (Columba livia $f$. domestica). Avian Dis, 49, 442-445.

Fulton RM, Thoen Co (2000). Tuberculosis. In. Diseases of Poultry, Ed: Saif YM, 11th Ed., 836-844, Iowa State Press, Ames.

Garcia A, LeClear C, Gaskin J (2001). Mycobacterium avium infection in an ostrich. (Struthio camelus). J Zoo Wildl Med, 32, 96-100.
Gerhold and Fischer 2005; Kriz et al. 2010). This disease leads to loss of yield, so it has been eradicated by modern poultry companies. However, it can be observed in wild birds (Thoen and Karlson 1991; Bougiouklis 2005). In poultry tuberculosis, lesions usually occur in the liver, spleen, intestines and bone marrow. Rarely, lung, heart, kidney, pancreas, brain, ovary, testis, skeletal muscles, skin, face, beak and eye can be found around. Although lesions vary in size and number, they are yellow-greywhite nodules (Fulton and Thoen 2000; Tell et al. 2003; Bougiouklis 2005). In the present case, the lesion was seen microscopically in the rock mosque pigeon only when the similar nodule was seen during the trimming process after the first fixation. In one of tumbler pigeons, similar nodular structures were seen under the right wing, liver, intestine and lung.

Histopathological examination of central caseous necrosis, multinucleated giant cells, epithelioid histiocytes, lymphocyte and inflammation table consisting of histiocytes is observed. This inflammation consisting of fibrocytes and fibroblasts around the encapsulated cells are restricted to a varying thickness (Thoen and Karlson 1991; Garcia et al. 2001; Gonzalez et al. 2002; Tell et al. 2003; Gerhold and Fischer 2005; Bougiouklis 2005; Terim Kapakin et al. 2010; Terim Kapakin and Alçı̆̆ır 2009). Microscopic lesions were consistent with those reported in the literature. Calcification observed in both human and mammalian tubercles is very rare in poultry tuberculosis (Fulton and Thoen 2000). Although rare calcification areas are observed in the reported cases, calcification was observed in almost all necrosis areas in this case. The tuberculosis agents are seen as small globules in small groups in the Ziehl-Neelsen special staining (Fulton and Thoen 2000; Özcan et al. 2001; Gonzalez et al. 2002; Tell et al. 2003; Gerhold and Fischer 2005; Bougiouklis 2005; Terim Kapakin et al. 2010). Microscopic lesions in the implanted pigeons were consistent with those reported in the literature. Microbiological examinations performed for the isolation of the three of the pigeons were negative. The cause of the negativity is not explained to the pigeons, but it is attributed to the animal owner giving antibiotic treatment in the pigeons.

The fact that a large part of the rock pigeons is found free in nature makes it difficult to detect the dead animals. Generally, the use of mosque roofs and squares as shelter areas causes difficulties in taking measures. These pigeons, which are fed by young children in the courtyard and squares of mosques, pose a potential danger to the air by the respiratory tract for other animals and people with their feces carrying dust and contaminated soil during their flight. In Turkey, a tumbler pigeon breeding is carried out in order to obtain both pleasure and economic income in some regions and this situation is increasing day by day. The fact that rarely literature data on pigeon tuberculosis is also emphasized in this case report since it can be important for pigeon breeding.

Gerhold RW, Fischer JR (2005). Avian tuberculosis in a wild turkey. Avian Dis, 49 (1), 164-166.

Gonzalez M, Rodriguez-Bertos A, Gimeno I, Flores JM, Pizarro M (2002). Outbreak of avian tuberculosis in 48-week-old commercial layer hen flock. Avian Dis, 46 (4),1055-1061.

Hejlicek K, Treml F (1994). Epizootiology and pathogenesis of avian mycobacteriosis in domestic pigeons (Columba livia f. domestica). Vet. Med, 39 (10),615-624.

Hsieh YC, Tsai KY, Wang CY, Hung CN, Tsai SS, Liu HJ (2009). Diagnosis of avian tuberculosis in Swinhoe's pheasants. Using conventional and molecular-based techniques. Avian Dis, 53, 629-33. 
Kriz P, Slaný M, Shitaye JE, Pavlík I (2010). Avian mycobacteriosis in humans remains a threat in the Czech Republic. Klin Mikrobiol Infekc Lek, 16 (1), 10-17.

Lennox AM (2007) Mycobacteriosis in companion psittacine birds: a review. J. Avian Med Surg, 21, 181-187.

Möbius P, Lentzsch P, Moser I, Naumann L, Martin G, Köhler H (2006). Comparative macrorestriction and RFLP analysis of Mycobacterium avium subsp. avium and Mycobacterium avium subsp. hominissuis isolates from man, pig, and cattle. Vet Microbiol, 117, 284-291.

Oruç E, Bali AF (2004). Tuberculosis in a young ostrich. Veterinarium, 1 , 23-26.

Özcan K, Beytut E, Tuzcu M (2001). Tuberculosis in geese (Anser anser) in Turkey. Avian Dis, 45, 755-759.
Singbeil BA, Bickford AA, Stoltz JH (1993). Isolation of Mycobacterium avium from ringneck pheasants (Phasianus colchicus). Avian Dis, 37 612-615.

Tell L, Woods L, Foley J, Needham M, Walker RA (2003). Model of avian mycobacteriosis: clinical and histopathologic findings in Japanese quail (Coturnix coturnix japonica) intravenously inoculated with Mycobacterium avium. Avian Dis, 47, 433-443.

Terim Kapakin KA, Sağlam YS, Altun S (2010).

Terim Kapakin KA, Alçığır G (2009). Bir güvercinde tüberküloz olgusu. Kafkas Univ Vet Fak Derg, 15 (3), 477-479.

Thoen CO, Karlson AG (1991). Tuberculosis. In, Diseases of Poultry, Ed Calnek BW, Barnes HJC, Beard W, Reid MW, Yoder HW, 9th Ed., 172185, Iowa State University Press, Ames. 